\title{
Effects of Poverty on Mental Health and Resilience among Rural Females of Haryana
}

\author{
Anil Kumar ${ }^{1 *}$, Dr. Rakesh Kumar Behmani ${ }^{2}$
}

\section{ABSTRACT}

In this present study examined the effects of poverty on mental health and resilience among females of rural Haryana. In every country, poverty stands as the biggest barricade in the development of economy. Total 200 BPL and APL females were taken as a sample from Haryana in this study. Mental health and resilience were measured with the help of Mental Health Questionnaire (Srivastava \& Bhatt, 1973) and Resilience Scale (Urmi Nanda \& Janak Pandey, 2002) among Below Poverty Line (BPL) females, Above Poverty Line (APL) females. Results indicated that significant differences between BPL and APL female on the dimensions of external resourcefulness, obsession compulsion, phobia and somatic anxiety. Above Poverty Line females are more prone to obsessive thought, compulsive behaviour, phobia and somatic anxiety symptoms. Economic conditions of females have no significant effect on resilience capacity of BPL and APL rural women in Haryana.

Keywords: Resilience, Mental Health, Below Poverty Line (BPL) females, Above Poverty Line (APL) females, Hysteria

Poverty is a state in which a human being or community is disadvantaged of, and or lacks the fundamentals for a least standard of well-being and existence. Poverty stands as the biggest barrier in the development of any economy. India being a developing country fall victim to poverty. The government authorities have been struggling hard to create policies which may prove beneficial in eradicating it. Poverty deprives an individual of security and well being. It snatches away the fundamentals for the existence of an individual. These fundamentals may be material assets such as food, safe drinking water, clothing and shelter or they may be social assets such as access to information, education, healthcare, social status and opportunity. Poor people have fairly low living standards as compared to people with high economic status. The

\footnotetext{
${ }^{1}$ Research Scholar, Dept. Of Applied Psychology, Guru Jambheshwer University of Science and Technology, Hisar, India

${ }^{2}$ Associate professor, Dept. Of Applied Psychology, Guru Jambheshwer University S \& T, Hisar, India *Responding Author
}

Received: November 11, 2016; Revision Received: March 3, 2017; Accepted: March 10, 2017

(C) 2017 Kumar A, Behmani R; licensee IJIP. This is an Open Access Research distributed under the terms of the Creative Commons Attribution License (www.creativecommons.org/licenses/by/2.0), which permits unrestricted use, distribution, and reproduction in any Medium, provided the original work is properly cited. 


\section{Effects of Poverty on Mental Health and Resilience among Rural Females of Haryana}

people who are living in poverty cannot afford to buy requirements and experience real deprivation and hardships in everyday life (McClelland, 2000).

Poverty is a feature of family as well as individual. People are defined as poor or rich depending on the financial status of their family. Persistently poor people are not capable to approach good quality foods and life style. Grants and Hulme (2004) considered that Health service expenditures are often far from the needs of the poors and can leave them dependent on the further accessible but lower quality and often expensive private service providers. Material and social denial are the two long standing factor linked to poverty (Commins, 2004). Material deprivation is related to survival needs and it encompasses inability to apply influence over decision making that affect one's quality of life. People can be deprived from many basic essentials and maintaining relationships because of a lack of money. These impacts of poverty on constitutional rights and relationships are called 'social exclusion'.

\section{Rural Poverty}

Individual mental and physical health is influenced by the social environment through three most important mechanisms: personal relationships and networks, individual socioeconomic status, and background effects of the places in which people live (Link \& Phelan, 1996).

Blank (2005) indicates that rural poverty is dissimilar than urban poverty due to the lonely nature of many small communities, the dissimilar opportunities that are presented within rural economies. These small communities may be ill-treated and kept aloof from the least available resources. The level of superstitions and caste system is also found high in rural areas which may be responsible for the deteriorating condition of poor people. The rising gap between the development of the urban area and the underdevelopment of rural areas also gives rise to poverty. India being an agriculture based country is largely dependent on farming for living. Hence, people are inclined toward having greater number of children so that they may contribute to the family income. This leads to rise in population which ultimately results in rising poverty. The government schemes to control population do not reach the poor people. The rural areas are more oriented towards having more number of males in the family; therefore the women in such families are forced to give birth to boys despite of large number of children in the families. This disrupted family structure keeps the mother engaged in taking care of the children and physical problems are generally experienced by rural females. Hence, they are not able to contribute to the family income. Therefore, the pressure on the single earning parents multiplies many folds whose income is not sufficient for the wellbeing of the family. Poverty stricken people are prone

to several deadly diseases due to lack of proper sanitation and healthy environment. In the absence of sufficient medical aids many children and mothers experience early death. Children in such environments are often seen as falling prey to malnutrition and under weight. People living in poverty do not have enough financial sources to receive education and basic health care facilities. Such families work hard to make both ends meet. Therefore, poverty is an ill condition 


\section{Effects of Poverty on Mental Health and Resilience among Rural Females of Haryana}

in which well being of an individual is disturbed due to lack of basic facilities of food, shelter and clothes.

In rural areas an absence of welfare and supports, rural poverty tends to be more hidden (Commins 2004; Milbourne 2010; Sherman 2006). The concept of hidden poverty is often observed in rural areas. The agriculture job may require less number of labour but in the need for earning a living, large number of people self employ themselves for a smaller work. This produces many unskilled-labours and also decreases the wage rate due to large availability of them. These unskilled labourers when move to town are often rejected and fall victim to poverty. Rural persons are more likely to experience and live in poverty. The rural areas do not get the necessary education about technology and government related schemes. The mediators also play an important role in the deteriorating condition of poor. The middle class families are more prone to show themselves as poor, which enables them to take most of the benefits of the government policies living the poverty stricken people in worst conditions. The mental set of the poor people do not let them to trust in the government. They take long time to adapt to these policies and hence are not able to gain benefits from them. This passive role of the poor does not let them to raise their standards as they start assuming the current lifestyle to be a part of their fate. (Finnie and Sweetman 2003; Jacob et al. 1997; Rural Welfare Policy Panel 1999; Sherman 2006). Researches proposed realties have more pessimistic attitudes toward poverty and receiving government support (Larson 1978; Osgood 1977). The stigma of poverty is greater in rural places than big cities because the rural poor live where poverty is seen as shameful and people develop a sense inadequacy.

\section{Mental Health}

Mental health related to physical health has been defined as absence of illness (Ryff\& Singer, 1998).Mental health is the capacity of an individual to make tuneful adjustments to one's social and physical surroundings. Mental health is described as nonappearance of symptoms of maladjustment. Mentally healthy person is free from all kind of maladjustment (Klein, 1956). According to the World Health Organization (WHO, 2001), mental health has become a major international health issue. About 450 million people globally are experiencing mental, neurological or behavioral difficulties at any time. According to the WHO report, mentally ill people are often subjected to social isolation and poor kind quality of life and higher mortality.

\section{Poverty and Mental Health}

Poverty is an important issue. This issue has implications for both physical and mental health. Poverty and social discrimination have direct and indirect effects on the social, mental and physical well-being of a human being. It is generally said that poverty can be both a determinant

and a consequence of poor mental health (Lanner \& Michael, 1963). Poverty is a major factor which affects people's health, access to fundamental needs and limiting the ability to completely participate in societal decisions, causing stress and restricting choices people make. Depression, 


\section{Effects of Poverty on Mental Health and Resilience among Rural Females of Haryana}

anxiety and other psychological symptoms of stress and low socio-economic status also negatively affect mental health of people (Beiger, Hour, Herman, \& Tousignant, 2002; Coburn, 2004). American, British and Canadian researchers have continuously found a positive correlation between low income and experiencing mental health problems (Beiser, Hou, et al., 2002; Nazroo, 2003; Raphael, 2001; Williams \& Collins, 1995). People living in poverty experience depression and many related psychological symptoms at higher rates than the rest of people. Rural people experience higher rates of violent injury, major depressive disorder and suicide as compared to their urban people (Dennis \& Pallotta, 2001). Women with mental health problems are more likely to experience physical health problems, which increase their chances of living in an already disadvantaged situation. Carla, J. Groh (2007) in a study suggested that poverty is consistently correlated with depression. However the burden always falls on poor women as a result of depression. Kessler et al. (2003) observed a higher 12-month incidence of major depressive disorder for those living in or near low financial situation. A. Kuruvilla and K.S. Jacob (2007) in their study uses the epidemiological data on psychological illness among the different socio-economic groups observed that stress due to social events and mental health problem is significantly correlated with poverty. Poverty affects through economic stressors such as unemployment and inaccessibility of accommodation leads to mental illness and lack of control in one's life.

Poverty and social inequality have direct and indirect effects on the social, mental and physical well-being of an individual. It is important to note that poverty and inequality are linked closely. Wilkinson (1997) believed that income inequality produces psychological stress, which leads to deteriorating health and higher mortality over time. The effect of income inequality also spills over into society causing stress, frustration and family disruption, which may increase the rate of crime, homicide and violence. Poverty is associated with many problems such as poor health, school failure, relationship problems, crime and substance abuse. Poor people belonging to the manual class are seen to have high alcohol dependency and drug abuse. The rural area is found more prone to substance misuse because availability of cheap roadside drugs is high. Lack of awareness in the rural areas may also result in poor mental health which leads to disrupted lifestyle.

\section{Resilience}

Resilience is the capacity to adapt positively to adverse situation. It is a psychological construct (Aspinwall\& McNamara, 2005). Resilience is defined as a concept that even in situations of multiple risks to an individual's development, there are certain qualities within the individual or his environment that allow him to deal with adverse situations (Engle et al., 1996). The capacity for resilience differ from individual to individual, family to family and this may grow or decline with time, depending on protective factors within the person that might prevent the negative impacts of adverse stressful situations or conditions (Henderson \& Milstein, 1996). The concept of family resiliency is relatively new. Family resiliency is the capability of the family to maintain 


\section{Effects of Poverty on Mental Health and Resilience among Rural Females of Haryana}

positive level of functioning and successfully adapt to challenges and situations in one's life (Patterson, 1997). Some studies have shown that in many situations, poor families are successful in making good decisions and in problem solving (Melo, 1995; Rosenberg, 1994). Resilient individuals are motivated to see problems as opportunities. In other words, resilient individuals seem not only to cope well with stressors but actually to experience such challenges as learning and development opportunities. Garmezy (1999) focuses on the relevancy of studying resilience in the context of poverty.

\section{Poverty and Resilience}

Resilience refers to the dynamic process of adaptation in the context of adversity (Luthar et al., 2000; Werner \& Smith, 1992). Two factors must be present for the occurrence of resilience. First, there must be adversity. Second, the person who is resilient must positively adjust in the face of this difficulty (Luthar, 2000). This is important to note that resilience is characterized by an individual's ability to reach just an average level of achievement and does not refer to poor children's abilities to overachieve, or exceed what their middle class counterparts are capable of. Resilience is promoted by protective factors and constrained by risk factors.

Early works consist of a group of three longitudinal studies of children and their families. The first study conducted by Rutter (1987) on children born to mentally ill parents found that many of the children were mentally healthy and appeared to be normal. The dependent variables used in this work tended to be negative. The researchers concluded that resilience is a positive reaction to stress and adversity (Rutter, 1990). A second set of longitudinal work done by Werner (1993) and Werner and Smith (1977) followed children in Kauai over a period of thirty years. Results of the study indicated that about one third of the children identified as at-risk because of poverty and dysfunction in the family developed into capable adults. This work approached resilience from a perspective of sustained competence under stress (Werner \& Smith, 1977).

A final set of longitudinal work done by Garmezy (1991) and Garmezy et al. (1984) investigated children from small earnings and conflicted families and some of the children were identified as less and free of pessimistic behaviors. In this research, resilience was defined as the capacity for recovery and maintaining adaptive functioning (Garmezy, 1991).Empirical understanding of socio-economic resilience and its links with poverty and socioeconomic vulnerability are incomplete (Cutter et al., 2008). A few empirical studies that have addressed socio-economic resilience have confined themselves to the study of adaptive and response capability (Tadele and Manyena, 2009; Alam and Collins, 2010; Paul and Routray, 2011).

\section{Poverty and Females}

One of the main differences between men and women in the context of poverty is women are more and easily affected with the consequences of poverty. The negative consequences of 


\section{Effects of Poverty on Mental Health and Resilience among Rural Females of Haryana}

poverty more on women than men, it is called feminization of poverty. The feminization of poverty may also be understood as an increase of women poverty rate as compared to men. Poverty and its effects are the main areas of interest for the researchers. Poverty is one of the most consistent predictors of depression in women because it imposes considerable stress while attacking many potential source of social support. Women being in motherhood find themselves more responsible to provide food and security for the family members. When not able to fulfil these needs, they experience high level of stress which may become a root cause of various mental disorders. These poor conditions also make women frustrated and violent. In such cases they end up harming their children or themselves. High levels of depressive symptoms are common among those with low socio economic status. Ennis et al .(2000) in their study found that poor women experience income, especially mother with young children more frequent and more uncontrolled life events than does the general population ,particularly in the context of chronic deprivation. Oakley and Rajan (1991) found that British working class women were more isolated and received less help than did women who were more economically secure. Women in the family are at the great risk of developing mental health problems. With limited number of resources, low income women engage in many creative strategies to cope with difficulties (Banyard, 1995). The low status of women in patriarchal families forces them to adopt carefree attitude towards others which becomes the basis of major development related issues in poor children. Not surprisingly, long term economic problems associated with diminished sense of efficacy, while increase in household income increase the sense of personal efficacy in women who head household (Downey \& Moen, 1987). From the human capital theory Becker (1964) proposed that women in general have high poverty risk than men.

\section{Criteria for Below Poverty Line (BPL) and Above Poverty Line (APL)}

Poverty is one of the prominent problems in many developing countries even in India also. From many decades ago, the government of India has been keen interested in knowing the actual position of poor families and dealing with this problem through various welfare programmes. The government has been adopted various criteria for measurement of poverty in rural and urban areas. After conducting a number of studies on general population, citizens is characterized into two categories namely Below Poverty Line (BPL) and Above Poverty Line (APL). The criteria laid down by government of India in 2011, we have followed the same criteria in this study. The household who had the income below 27000 falls below the poverty line. Same as, people who earns 27 rupees per day in rural areas and 33 in urban areas shall be deemed as Below Poverty Line (BPL) families by government of India. Government of India has decided to rectify the criteria for determining the poverty line replaced the 2011 formula. A large number of people in India were living Below Poverty Line and experiencing different odds and challenges in everyday life. The present study was conducted on Below Poverty Line (BPL) and Above Poverty Line (APL). Our criterion for selection of Below Poverty Line (BPL) was based on yellow ration card issued by government to rural and urban families. Below Poverty Line (BPL) families are those who are having very low income and subject to live in adverse life 


\section{Effects of Poverty on Mental Health and Resilience among Rural Females of Haryana}

experiences. On the other hand, Above Poverty Line (APL) families are those who have been issued green ration card, generally considered middle or high class families.

\section{Objective}

1. To study the significance of difference between BPL and APL on the dimensions of resilience.

2. To study the significance of difference between BPL and APL on the dimensions of mental health.

\section{Hypothesis}

1. There shall be no significant difference between BPL and APL rural women on the dimensions of resilience.

2. There shall be no significance difference between BPL and APL rural women on the dimensions of mental health.

\section{METHODOLOGY}

\section{Sample}

Sample consists of 200 persons in which 100 BPL persons and 100 APL persons from different rural areas of Haryana.

\section{Psychological Measures}

Resilience scale- The scale used in this research was originally developed by Urmi Nanda in the supervision of Prof. Janak Pandey (2002) in an attempt to know the capacity of people to cope and recover from adverse situation. There are total 32 items in this scale Consists of four subdimensions namely preservance, external resourcefulness, internal resourcefulness and positive orientation. The alpha value for the overall scale is .86. The four dimension and their corresponding alpha values are: preservance (.68), external resourcefulness (.54), internal resourcefulness (.62), positive orientation / coping (.70).

Mental Health Questionnaire (Srivastava and Bhatt, 1973): Mental health Questionnaire consists of 48 items and it covers the following six dimensions of sound mental health and psychological well being. It include free floating anxiety, obsessional traits and symptoms, phobic anxiety, somatic commitants of anxiety, neurotic depression, hysterical personality traits to measure mental ill health of the individual.

\section{Procedure}

After establishing rapport with the participants' psychological measures the mental health questionnaire and life satisfaction scale was administered on BPL and APL female persons. They were assisted in completion of filling questionnaires. After getting all answers of the test, subjects were greeted and finally obtained data was analyzed with the help of Pearson product moment correlation and one way Anova and results were discussed.

(c) The International Journal of Indian Psychology, ISSN 2348-5396 (e)| ISSN: 2349-3429 (p) | 31 


\section{RESULTS AND DISCUSSION}

The relationship among the various variables was studied by using pearson product moment correlation while the difference were studied using the t-test. The results are represented in table no 1 to 4.

Table No: 1 Mean and SD for BPL and APL female groups

\begin{tabular}{|l|c|c|c|c|}
\hline & \multicolumn{2}{|c|}{ Below Poverty Line (BPL) } & \multicolumn{2}{l|}{ Above Poverty Line (APL) } \\
\hline Variables & Mean & SD & Mean & SD \\
\hline Resilience Preservance & 15.99 & 2.71 & 15.97 & 2.81 \\
\hline $\begin{array}{l}\text { Resilience External } \\
\text { Resourcefulness }\end{array}$ & 16.29 & 2.61 & 16.79 & 2.01 \\
\hline $\begin{array}{l}\text { Resilience internal } \\
\text { Resourcefulness }\end{array}$ & 24.81 & 3.99 & 23.70 & 4.41 \\
\hline Resilience positive Orientation & 29.77 & 4.27 & 28.87 & 4.86 \\
\hline MH Free Floating Anxiety & 7.68 & 2.54 & 8.37 & 2.47 \\
\hline MH Obsession & 9.00 & 2.81 & 9.66 & 2.18 \\
\hline MH Phobia & 8.62 & 3.03 & 9.30 & 2.19 \\
\hline MH FOC & 8.11 & 2.19 & 8.65 & 2.37 \\
\hline MH Depression & 7.62 & 3.11 & 7.95 & 2.61 \\
\hline MH Hysteria & 7.72 & 2.57 & 8.53 & 2.48 \\
\hline
\end{tabular}

Table no 1 represents the Mean and SD for BPL and APL female persons. The results in the table revealed there is a minor difference between both groups on the dimensions of Resilience and Mental Health. However, a significant difference was found in the mean value of BPL and APL female persons.

Table No 2 Interco-relation matrix for Above Poverty Line (APL)

\begin{tabular}{|c|c|c|c|c|c|c|c|c|c|c|}
\hline variables & $\begin{array}{l}\text { Resilie } \\
\text { nce } \\
\text { preserv } \\
\text { ance }\end{array}$ & $\begin{array}{l}\text { Resilience } \\
\text { External } \\
\text { Resourcef } \\
\text { ulness }\end{array}$ & $\begin{array}{l}\text { Resilience } \\
\text { Internal } \\
\text { Resourcef } \\
\text { ulness }\end{array}$ & 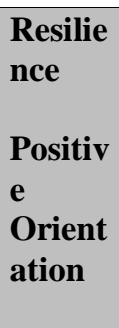 & $\begin{array}{l}\text { MH } \\
\text { Free } \\
\text { Float } \\
\text { ing } \\
\text { Anxi } \\
\text { ety }\end{array}$ & $\begin{array}{l}\text { MH } \\
\text { Obsessi } \\
\text { ve } \\
\text { Compu } \\
\text { lsion }\end{array}$ & $\begin{array}{l}\text { MH } \\
\text { Pho } \\
\text { bia }\end{array}$ & $\begin{array}{l}\text { MH } \\
\text { Somm } \\
\text { atic } \\
\text { Comit } \\
\text { ant Of } \\
\text { Anxie } \\
\text { ty }\end{array}$ & $\begin{array}{l}\text { MH } \\
\text { Depres } \\
\text { sion }\end{array}$ & $\begin{array}{l}\text { MH } \\
\text { Hyst } \\
\text { eria }\end{array}$ \\
\hline $\begin{array}{l}\text { Resilience } \\
\text { Preservan } \\
\text { ce }\end{array}$ & 1 & .02 & $.28^{* *}$ & .15 & $\begin{array}{c}- \\
.33^{* *}\end{array}$ & -.14 & -.19 & -.12 & $-.19 *$ & -.10 \\
\hline $\begin{array}{l}\text { Resilience } \\
\text { External } \\
\text { Resourcef } \\
\text { ulness }\end{array}$ & .02 & 1 & .02 & .03 & .01 & .03 & .03 & -.04 & .06 & -.02 \\
\hline $\begin{array}{l}\text { Resilience } \\
\text { Internal } \\
\text { Resourcef } \\
\text { ulness }\end{array}$ & .28 & .02 & 1 & -.01 & $\begin{array}{c}- \\
.33 * *\end{array}$ & -.03 & -.05 & -.09 & $-.23^{*}$ & $-.23^{*}$ \\
\hline
\end{tabular}


Effects of Poverty on Mental Health and Resilience among Rural Females of Haryana

\begin{tabular}{|c|c|c|c|c|c|c|c|c|c|c|}
\hline variables & $\begin{array}{l}\text { Resilie } \\
\text { nce } \\
\text { preserv } \\
\text { ance }\end{array}$ & $\begin{array}{l}\text { Resilience } \\
\text { External } \\
\text { Resourcef } \\
\text { ulness }\end{array}$ & $\begin{array}{l}\text { Resilience } \\
\text { Internal } \\
\text { Resourcef } \\
\text { ulness }\end{array}$ & 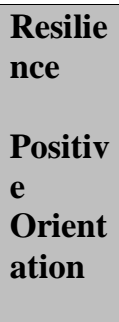 & $\begin{array}{l}\text { MH } \\
\text { Free } \\
\text { Float } \\
\text { ing } \\
\text { Anxi } \\
\text { ety }\end{array}$ & $\begin{array}{l}\text { MH } \\
\text { Obsessi } \\
\text { ve } \\
\text { Compu } \\
\text { lsion }\end{array}$ & $\begin{array}{l}\text { MH } \\
\text { Pho } \\
\text { bia }\end{array}$ & $\begin{array}{l}\text { MH } \\
\text { Somm } \\
\text { atic } \\
\text { Comit } \\
\text { ant Of } \\
\text { Anxie } \\
\text { ty }\end{array}$ & $\begin{array}{l}\text { MH } \\
\text { Depres } \\
\text { sion }\end{array}$ & $\begin{array}{l}\text { MH } \\
\text { Hyst } \\
\text { eria }\end{array}$ \\
\hline $\begin{array}{l}\text { Positive } \\
\text { Orientatio } \\
\text { n }\end{array}$ & .15 & .03 & -.01 & 1 & $-.25 *$ & -.05 & .18 & -.06 & -.15 & -.15 \\
\hline $\begin{array}{l}\text { MH Free } \\
\text { Floating } \\
\text { Anxiety }\end{array}$ & $-.335^{* *}$ & .010 & $-.335^{* *}$ & $-.249^{*}$ & 1 & .182 & .208 & $.288^{* *}$ & $.334^{* *}$ & $.349^{*}$ \\
\hline $\begin{array}{l}\text { MH } \\
\text { Obsessive } \\
\text { Compulsi } \\
\text { on }\end{array}$ & -.144 & .029 & -.033 & -.053 & .182 & 1 & .100 & $.284^{* *}$ & .183 & .104 \\
\hline $\begin{array}{l}\text { MH } \\
\text { Phobia }\end{array}$ & -.195 & .026 & -.055 & .177 & $.208^{*}$ & .100 & 1 & $.257^{* *}$ & -.052 & .069 \\
\hline $\begin{array}{l}\text { MH } \\
\text { Somatic } \\
\text { Comitant } \\
\text { of } \\
\text { Anxiety }\end{array}$ & -.124 & -.041 & -.091 & -.058 & $.288^{*}$ & $.284^{* *}$ & .257 & 1 & .168 & .162 \\
\hline $\begin{array}{l}\text { MH } \\
\text { Depressio } \\
\text { n }\end{array}$ & $-.199^{*}$ & .061 & $-.232^{*}$ & -.151 & $.334^{*}$ & .183 & $\begin{array}{c}- \\
.052\end{array}$ & .168 & 1 & $.247^{*}$ \\
\hline $\begin{array}{l}\text { MH } \\
\text { Hysteria }\end{array}$ & -.096 & -.016 & $-.230^{*}$ & -.151 & $.349^{*}$ & .104 & .069 & .162 & $.247^{*}$ & 1 \\
\hline
\end{tabular}

According to the content of table 2, perservance is significant negatively correlated with free floating anxiety $(\mathrm{r}=0-.33, \mathrm{p}<.01)$ and $(\mathrm{r}=0-.20, \mathrm{p}<.05)$ depression. However, internal resourcefulness is negatively correlated with free floating anxiety $(\mathrm{r}=0-.33, \mathrm{p}<.01)$, depression $(\mathrm{r}=0.23, \mathrm{p}<.05)$ and $(\mathrm{r}=0-.23, \mathrm{p}<.05)$ hysteria. Positive orientation is negatively correlated with $(\mathrm{r}=0-.25, \mathrm{p}<.05)$ free floating anxiety for APL rural females in Haryana.

Table No 3Inter-Correlation between Resilience and Mental Health for Below Poverty Line (BPL)

\begin{tabular}{|c|c|c|c|c|c|c|c|c|c|c|}
\hline variables & 1 & 2 & 3 & 4 & 5 & 6 & 7 & 8 & 9 & 10 \\
\hline $\begin{array}{ll}\text { 1. } & \text { Resilience } \\
& \text { Preservance } \\
\end{array}$ & 1 & & & & & & & & & \\
\hline $\begin{array}{ll}\text { 2. } & \text { External } \\
& \text { Resourcefulness }\end{array}$ & .163 & 1 & & & & & & & & \\
\hline $\begin{array}{ll}\text { 3. } & \text { Internal } \\
& \text { Resourcefulness }\end{array}$ & .035 & $.338^{* *}$ & 1 & & & & & & & \\
\hline $\begin{array}{ll}\text { 4. } & \text { Positive } \\
\text { Orientation }\end{array}$ & $.257^{* *}$ & $.291^{* *}$ & $.486^{* *}$ & 1 & & & & & & \\
\hline $\begin{array}{l}\text { 5. MH Free Floating } \\
\text { Anxiety }\end{array}$ & $.242^{*}$ & -.076 & $.285^{* *}$ & $.287^{* *}$ & 1 & & & & & \\
\hline
\end{tabular}

(C) The International Journal of Indian Psychology, ISSN 2348-5396 (e)| ISSN: 2349-3429 (p) | 33 
Effects of Poverty on Mental Health and Resilience among Rural Females of Haryana

\begin{tabular}{|c|c|c|c|c|c|c|c|c|c|c|}
\hline variables & 1 & 2 & 3 & 4 & 5 & 6 & 7 & 8 & 9 & 10 \\
\hline $\begin{array}{ll}\text { 6. MH Obsessive } \\
\text { Compulsion }\end{array}$ & -.165 & -.041 & .063 & .065 & $.395^{* *}$ & 1 & & & & \\
\hline 7. MH Phobia & $.289^{* *}$ & -.108 & -.172 & -.110 & $.622^{* *}$ & $.512^{* *}$ & 1 & & & \\
\hline $\begin{array}{l}\text { 8. MH Summative } \\
\text { Comitant of } \\
\text { Anxiety } \\
\end{array}$ & -.096 & -.047 & -.115 & -.043 & $.481^{* *}$ & $.367^{* *}$ & $.539^{* *}$ & 1 & & \\
\hline 9. MH Depression & $.310^{* *}$ & -.173 & $.279^{* *}$ & $.241^{*}$ & $.501^{* *}$ & $.369^{* *}$ & $.521^{* *}$ & $.408^{* *}$ & 1 & \\
\hline 10. MH Hysteria & -.076 & ${ }^{-}$ & $.310^{* *}$ & $.289^{* *}$ & $.425^{* *}$ & .180 & $.371^{* *}$ & $.310^{* *}$ & $.331^{* *}$ & 1 \\
\hline
\end{tabular}

According to table no 3, perservance is negatively correlated ( $\mathrm{r}=0-.24, \mathrm{p}<.05$ ) with free floating anxiety, phobia $(\mathrm{r}=0-.29, \mathrm{p}<.01)$ and depression $(\mathrm{r}=0-.31, \mathrm{p}<.05)$ for rural BPL females in Haryana. There is significant negative correlation between external resourcefulness $(r=0-.23$, $\mathrm{p}<.05$ ) and hysteria. Other findings of the study showed that internal resourcefulness is significant negatively correlated with $(\mathrm{r}=0-.28, \mathrm{p}<.01)$ free floating anxiety, depression $(\mathrm{r}=0-.28$, $\mathrm{p}<.01)$ and hysteria $(\mathrm{r}=0-.31, \mathrm{p}<.05)$. Results also showed that positive orientation is negative significantly correlated $(\mathrm{r}=0-.29, \mathrm{p}<.01)$, depression $(\mathrm{r}=0-.24, \mathrm{p}<.05)$ and $(\mathrm{r}=0-.29, \mathrm{p}<.01)$ hysteria.

Table No 4. Mean SD and t-Values indicating difference between BPL and APL rural women on the dimension of Resilience and Mental Health.

\begin{tabular}{|c|c|c|c|c|c|c|}
\hline Variable & Group & $\mathbf{N}$ & df & Mean & SD & t \\
\hline $\begin{array}{l}\text { Resilience } \\
\text { Preservance }\end{array}$ & $\begin{array}{l}\text { BPL } \\
\text { APL }\end{array}$ & 200 & 198 & $\begin{array}{l}15.99 \\
15.97\end{array}$ & $\begin{array}{l}2.71 \\
2.81\end{array}$ & .051 \\
\hline $\begin{array}{l}\text { Resilience } \\
\text { External } \\
\text { Resourcefulness } \\
\end{array}$ & $\begin{array}{l}\text { BPL } \\
\text { APL }\end{array}$ & 200 & 198 & $\begin{array}{l}16.29 \\
16.79\end{array}$ & $\begin{array}{l}2.61 \\
2.01\end{array}$ & $-1.51 * *$ \\
\hline $\begin{array}{l}\text { Resilience } \\
\text { internal } \\
\text { Resourcefulness }\end{array}$ & $\begin{array}{l}\text { BPL } \\
\text { APL }\end{array}$ & 200 & 198 & $\begin{array}{l}24.81 \\
23.70\end{array}$ & $\begin{array}{l}3.99 \\
4.41\end{array}$ & -1.86 \\
\hline $\begin{array}{l}\text { Resilience } \\
\text { positive } \\
\text { Orientation } \\
\end{array}$ & $\begin{array}{l}\text { BPL } \\
\text { APL }\end{array}$ & 200 & 198 & $\begin{array}{l}29.77 \\
28.87\end{array}$ & $\begin{array}{l}4.27 \\
4.86\end{array}$ & 1.39 \\
\hline $\begin{array}{l}\text { MH Free } \\
\text { Floating } \\
\text { Anxiety }\end{array}$ & $\begin{array}{l}\text { BPL } \\
\text { APL }\end{array}$ & 200 & 198 & $\begin{array}{l}7.68 \\
7.37\end{array}$ & $\begin{array}{l}2.54 \\
2.47\end{array}$ & 1.37 \\
\hline MH Obsession & $\begin{array}{l}\text { BPL } \\
\text { APL }\end{array}$ & 200 & 198 & $\begin{array}{l}9.00 \\
9.66 \\
\end{array}$ & $\begin{array}{l}2.81 \\
2.18 \\
\end{array}$ & $-1.85 * *$ \\
\hline MH Phobia & $\begin{array}{l}\text { BPL } \\
\text { APL }\end{array}$ & 200 & 198 & $\begin{array}{l}8.62 \\
9.30\end{array}$ & $\begin{array}{l}3.03 \\
2.19\end{array}$ & $-1.82 * *$ \\
\hline
\end{tabular}

(C) The International Journal of Indian Psychology, ISSN 2348-5396 (e)| ISSN: 2349-3429 (p) | 34 
Effects of Poverty on Mental Health and Resilience among Rural Females of Haryana

\begin{tabular}{|l|l|l|l|l|l|l|}
\hline Variable & Group & N & df & Mean & SD & t \\
\hline MH FOC & BPL & 200 & 198 & 8.11 & 2.91 & $-1.44^{*}$ \\
& APL & & & 8.65 & 2.37 & \\
\hline MH Depression & BPL & 200 & 198 & 7.62 & 3.11 & -.81 \\
& APL & & & 7.95 & 2.61 & \\
\hline MH Hysteria & BPL & 200 & 198 & 7.72 & 2.57 & -2.27 \\
& APL & & & 8.53 & 2.48 & \\
\hline
\end{tabular}

Table no 4 shows that there is no significant difference between BPL and APL on the dimensions of resilience and mental health. The results reveal that there is significant difference between BPL and APL on the dimension of external resourcefulness. Many studies conducted in Switzerland, Korea and Austria reported girl's students from high socio economic status are more likely to be determined for their work despite difficulty. Females belongs to APL are more likely to use feedback and information in difficult circumstances as compared to BPL. Further a significant difference was found between BPL and APL females on the dimension of obsession compulsion and phobia. These findings in the table represent that APL females are more obsessive and compulsive and more prone to phobia. G, Shams et al. (2010) in their study found that gender, age and family income had no statistically significant association with obsession compulsion symptoms. Studies carried out in developed countries have shown that social phobia is third most common mental disorder. Phobia is most prevalent among women in low SES (Funmark, 2002). In another study, Akhtar et al. (1975) found a significant correlation between high socioeconomic status and OCD. Studies carried out in developed countries have shown that Results in the table also reveal that significant difference between BPL and APL on the dimension of somatic anxiety. Results depict APL rural females are highly prone to symptoms of somatic anxiety in Haryana. Further results do not show any significant difference between BPL and APL on the dimension of depression and hysteria

\section{Limitations}

The present study is limited to mainly Below Poverty Line (BPL) and Above Poverty Line (APL) rural women in Haryana.In the present study demographic variables like age, religion, income level of Below Poverty Line (BPL) and Above Poverty Line (APL) have not been taken into consideration. These variables could have contributed more clear results.

\section{Acknowledgments}

The author appreciates all those who participated in the study and helped to facilitate the research process.

Conflict of Interests: The author declared no conflict of interests. 


\section{REFERENCES}

Alam, E., \& Collins, A.E. (2010). Cyclone disaster vulnerability and response experiences in coastal Bangladesh, Disasters, 34(4), 931-954.

Aspinwall, L.G.,\& McNamra, A.(2005). Taking positive changes seriously. Cancer, 104 (S11). 2549-2556.

Banyard, V. L. (1995). “Taking another route”: Daily survival narratives from mothers who are homeless. American journal of community psychology, 23(6), 871-891.

Becker, G. (1964). Human Capital. New Work: Columbia University Press.

Beiser, M., Hou, F., Hyman, I., \& M, Tousignant. (2002). Poverty, family process and the mental health of immigrant children in Canada. American Journal of Public Health, 92(2), 220-227.

Blank, R. (2005). Poverty, policy, and place: How poverty and policies to alleviate poverty are shaped by local characteristics. International Regional Science Review, 28(4), 441 - 464.

Charney, D. S. (2004). Psychobiological mechanisms of resilience and vulnerability. Focus.

Coburn, C. E. (2004). Beyond decoupling: Rethinking the relationship between the institutional environment and the classroom. Sociology of Education, 77(3), 211-244.

Commins, P. (2004). Poverty and social exclusion in rural areas: Characteristics, processes and research issues. Sociologia Ruralis, 44(1): 60-75.

Cutter, S. L., Barnes, L., Berry, M., Burton, C., Evans, E., Tate, E., \& Webb, J.(2008). A place based model for understanding community resilience to natural disasters. Global environmental change, 18(4), 598-606.

Dennis, L. K., \& Pallotta, S. L. (2001). Chronic disease in rural health. In Handbook of rural health (pp. 189-207).Springer US.

Downey, G., \& Moen, P. (1987). Personal efficacy, income, and family transitions: A longitudinal study of women heading households. Journal of Health and Social Behavior, 320-333.

Engle, P.L., Castle, S., \& P, Menon. (1996). Child Development: Vulnerability and Resilience. FCND DISCUSSION PAPER NO. 12. Food Consumption and Nutrition Division. International Food Policy Research Institute. http://www.ifpri.org/divs/fcnd/dp/papers/dp12.pdf

Ennis, N. E., Hobfoll, S. E., \& Schröder, K. E. (2000). Money doesn't talk, it swears: How economic stress and resistance resources impact inner-city women's depressive mood. American journal of community psychology, 28 (2), 149-173.

Finnie, R., \& A, Sweetman.(2003). Poverty dynamics: Empirical evidence for Canada. Canadian Journal of Economics, 36(2), 291-335.

Garmezy, N. (1991). Resiliency and vulnerability to adverse developmental outcomes associated with poverty. The American Behavioral Scientist, 34(4), 416.

Garmezy, N. (1999). Resilience: An interview with Norman Garmezy. In M. D. Glantz \& J. L. Johnson (Eds).Resilience and development: Positive life adaptation (pp. 5-14). New York: Plenum Press. 


\section{Effects of Poverty on Mental Health and Resilience among Rural Females of Haryana}

Garmezy, N., Masten, A. S., \& Tellegen, A. (1984). The study of stress and competence in children: A building block for developmental psychopathology. Child development, 97-111.

Grant, U., and Hulme, D. (2004). Service Delivery and the Poorest, Commissioned paper for the Reaching the Very Poorest Team, Department for International Development, UK.

Harrington, R., Fudge, H., Rutter, M., Pickles, A., \& Hill, J.(1990). Adult outcomes of childhood and adolescent depression: I. Psychiatric status. Archives of general psychiatry, 47(5), 465-473.

Henderson, N., \& Milsltein, M. (1996). Resiliency in schools: Making it happen for students and educators. Thousand Oaks, CA: Corwin Press.

Hudolin, V. (Ed.). (2013). Social psychiatry. Springer Science \& Business Media.

Jacob, S., Bourke, L., and A. Luloff. 1997. Rural community stress, distress, and well-being in Pennsylvania. Journal of Rural Studies, 13(3): 275-288.

Klein, E., Farber, S., Djerassi, I., Toch, R., Freeman, G., \& Arnold, P. (1956). The preparation and clinical administration of lyophilized platelet material to children with acute leukemia and aplastic anemia. The Journal of pediatrics, 49(5), 517-522.

Kuruvilla, A., \& Jacob, K. S. (2007). Poverty, social stress \& mental health. Indian Journal of Medical Research, 126(4), 273.

Langner, T. S., \& Michael, S. T. (1963). Life stress and mental health: II. The midtown Manhattan study.

Larson, R. (1978). Thirty years of research on the subjective well-being of older Americans. Journal of gerontology, 33(1), 109-125.

Link, B., \& Phelan, J. (1996). Understanding sociodemographic differences in health: The role of fundamental social causes. American Journal of Public Health, 86(4), 471-473.

Litwinczuk, K. M., \& Groh, C. J. (2007). The relationship between spirituality, purpose in life, and well-being in HIV-positive persons. Journal of the Association of Nurses in AIDS Care, 18(3), 13-22.

Luthar, S. S., Cicchetti, D., \& Becker, B. (2000). The construct of resilience: A critical evaluation and guidelines for future work. Child development, 71(3), 543-562.

Luthar, S. S., Cicchetti, D., \& Becker, B. (2000). The construct of resilience: A critical evaluation and guidelines for future work. Child development, 71(3), 543-562.

McClelland, A. (2000). No child ....Child poverty in Australia, summarized by Bette Moore in Child Poverty: the facts, Brotherhood of St Laurence, Fitzroy, Victoria.

Melo, S.L. (1995). Familia: perspective teorica e observacao factual, In Carvalho (org.). A familia contemporanea em debate. Sao Paulo: Educ.

Milbourne, P. (2010). The geographies of poverty and welfare. Geography Compass 4 (2): 158-171.

Nazroo, J. (2003). The structuring of ethnic inequalities in health: Economic position, racial discrimination, and racism. American Journal of Public Health, 93(2): 277-284.

Oakley, A.,\& Rajan, L. (1991). Social class and social support: the same or different? Sociology, 25(1), 31-59.

Osgood, C. E., \& Bock, J. K.(1977). Salience and sentencing: Some production principles. Sentence Production: Developments in Research and Theory, Rosenberg, S., Editor, 89-140. 


\section{Effects of Poverty on Mental Health and Resilience among Rural Females of Haryana}

Panday, J., \& N, Urmi.(2002). Resilience Scale. An unpublished standardized measure of resilience. Department of psychology, Allahabad University.

Patterson, J. (1997). Promoting resiliency in families. Resiliency In Action, (2), 8-16.

Paul, S.K., Routray, J.K.(2011). Household response to cyclone and induced surge in coastal Bangladesh: coping strategies and explanatory variables. Natural Hazards, 57(2), 477-499.

Raphael, D. (2001). Increasing poverty threatens the health of all Canadians. Canadian Family Physician, 47: 1703-1706.

Rural Welfare Policy Panel. (1999). Rural America and Welfare Reform: An Overview Assessment. Columbia, MO: Rural Policy Research Institute.

Rutter, M.(1987). Psychosocial resilience and protective mechanisms. American journal of orthopsychiatry, 57(3), 316.

Ryff, C. D., \& Singer, B.(1998). The contours of positive human health. Psychological inquiry, 9(1), 1-28.

Sherman, J. (2006). Coping with rural poverty: Economic survival and moral capital in rural America. Social Forces, 85(2), 891-913.

Sherman, J. (2006). Coping with rural poverty: Economic survival and moral capital in rural America. Social Forces, 85(2): 891-913.

Srivastava, O. N., \& Bhatt,V.Ku.(1973). Mental ill-health questionnaire. An unpublished standardized measure of mental health. Department of psychology, Banaras Hindu University.

Tadele, F., \& Bernard Manyena, S. (2009). Building disaster resilience through capacity building in Ethiopia. Disaster Prevention and Management: An International Journal, 18(3), 317-326.

Tadele, F., Manyena, S.B. (2009). Building disaster resilience through capacity building in Ethiopia. Disaster Prevention and Management, 18(3), 317-326.

Thorp, R., F, Stewart., \& A, Heyer. (2005). When and how far is group formation a route out of chronic poverty? World Development, 33(6): 907-920.

Van den Berg, M. (2010). Household income strategies and natural disasters: Dynamic livelihoods in rural Nicaragua. Ecological Economics, 69(3), 592-602.

Werner, E. E. (1993). Risk, resilience, and recovery: Perspectives from the Kauai Longitudinal Study. Development and psychopathology, 5(04), 503-515.

Werner, E. E., \& Smith, R. S. (1977). Kauai's children come of age. Honolulu: University Press of Hawaii.

Werner, E. E., \& Smith, R. S. (1992). Overcoming the odds: High risk children from birth to adulthood. Cornell University Press.

Williams, D., \& C, Collins.(1995). US socioeconomic and racial differences in health: Patterns and explanations. Annual Review of Sociology, 21.

World Health Organization. (2001). WHO global strategy for containment of antimicrobial resistance.

How to cite this article: Kumar A, Behmani R (2017), Effects of Poverty on Mental Health and Resilience among Rural Females of Haryana, International Journal of Indian Psychology, Volume 4, Issue 2, No. 93, ISSN:2348-5396 (e), ISSN:2349-3429 (p), DIP:18.01.123/20170402, ISBN:978-1-365-78193-3 